\title{
Çakıldak fındık çeşidinde iç meyve iriliğine bağlı olarak biyokimyasal özelliklerin değişimi
}

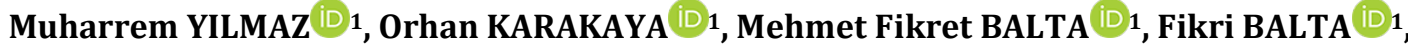 \\ İzzet YAMAN ${ }^{D} 1$
}

1Ordu Üniversitesi, Ziraat Fakültesi, Bahçe Bitkileri Bölümü, Altınordu, Ordu

Alınıș tarihi: 21 Kasım 2019, Kabul tarihi: 30 Aralık 2019

Sorumlu yazar: Mehmet Fikret BALTA, e-posta: fikret_balta@hotmail.com

\section{Öz}

Bu çalışma, Çakıldak fındık çeşidinde iç meyve iriliği ile biyokimyasal özellikler arasındaki ilişkiyi belirlemek amacı ile yürütülmüştür. $\mathrm{Bu}$ amaçla meyveler iç iriliğine göre küçük (9.0-11.0), orta (11.01-13.0) ve büyük (13.01-15.0) olmak üzere 3 gruba ayrılmıştır. İç meyve iriliğine göre sınıflandırılan meyvelerde yağ oranı, protein oranı, toplam fenolik içeriği, toplam flavonoid içeriği ve antioksidan kapasitesi (FRAP ve DPPH testlerine göre) belirlenmiştir. Protein oranı üzerine iç meyve iriliğinin etkisi önemsiz bulunurken ( $p>0.05)$, yağ oranı, toplam fenolik içeriği, toplam flavonoid içeriği ve antioksidan kapasitesi üzerine ise önemli bir etkisinin olduğu tespit edilmiştir $(\mathrm{p}<0.05)$. İç meyve iriliğine göre; yağ oranı \%56.74 (küçük)-58.02 (orta), protein oranı \%16.24 (küçük)-17.85 (büyük), toplam fenolik içeriği 662.3 (orta)-763.5 (küçük) mg $100 \mathrm{~g}^{-1}$, toplam flavonoid içeriği 5.42 (büyük)-11.56 (küçük) mg $100 \mathrm{~g}^{-1}$, FRAP testine göre antioksidan kapasitesi 3348.0 (orta)-5883.3 (küçük) $\mu \mathrm{mol} 100 \mathrm{~g}$ 1 ve DPPH testine göre ise 3160.0 (orta)-4418.2 (küçük) $\mu \mathrm{mol} 100 \mathrm{~g}^{-1}$ arasında belirlenmiştir. İç meyve iriliği ile toplam flavonoid içeriği ( $\mathrm{r}=$ $0.957^{* * *}$ ) ve antioksidan kapasitesi (FRAP ve DPPH testlerine göre, sirasıyla $r=-0.799^{* *}$ ve $r=-0.739 *$ ) arasında negatif bir korelasyon belirlenmiștir $(\mathrm{p}<0.05)$. Bunun yanı sıra iç meyve iriliği ile toplam flavonoid içeriği $\left(\mathrm{R}^{2}=0.917\right)$ ve antioksidan kapasitesi (FRAP ve DPPH testlerine göre, sırasıyla $\mathrm{R}^{2}=0.637$ ve $\mathrm{R}^{2}=0.546$ ) arasında negatif bir ilișki tespit edilmiştir $(\mathrm{p}<0.05)$. Sonuç olarak, yağ oranı bakımından orta irilikteki meyvelerin, protein oranı bakımından büyük irilikteki meyvelerin ve toplam fenolik içeriği, toplam flavonoid içeriği ve antioksidan kapasitesi bakımından ise küçük iç iriliğine sahip meyvelerin yüksek değerlere sahip olduğu belirlenmiştir.

Anahtar kelimeler: Fındık, yağ, protein, toplam fenolik, antioksidan

\section{Change of biochemical characteristics depending on kernel size in Çakıldak hazelnut cultivar}

\section{Abstract}

The study was conducted to determine reletaion in the among biochemical properties with kernel size in Çakıldak cultivar. For this purpose, kernels were divided into three groups as small (9.0-11.0), medium (11.01-13.0) and large (13.01-15.0) according to kernel size. In kernels classified according to kernel size were detected oil ratio, protein ratio, total phenolics content, total flavonoids content and antioxidant capacity (according to FRAP and DPPH assays). While the effect of kernel size on protein ratio was insignificant ( $p>0.05$ ), it was determined to have a significant effect on oil ratio, total phenolics content, total flavonoids content and antioxidant capacity $(\mathrm{p}<0.05)$. According to kernel size, was determined from $56.74 \%$ (small) to $58.02 \%$ (medium) for oil ratio, $16.24 \%$ (small) to $17.85 \%$ (büyük) for protein ratio, 662.3 (medium) to 763.5 (small) mg $100 \mathrm{~g}^{-1}$ for total phenolics content, 5.42 (large) to 11.56 (small) mg $100 \mathrm{~g}^{-1}$ for total flavonoids content, 3348.0 (medium) to 5883.3 (small) $\mu \mathrm{mol} 100 \mathrm{~g}^{-1}$ for antioxidant capacity according to FRAP assay and 
3160.0 (medium) to 4418.2 (small) $\mu$ mol $100 \mathrm{~g}^{-1}$ in according to DPPH assay. A negative correlation was detected between the kernel size with total flavonoids content $\left(\mathrm{r}=-0.957^{* * *}\right)$ and antioxidant capacity (according to FRAP and DPPH assays, $r=$ $0.799^{* *}$ and $\mathrm{r}=-0.739^{*}$, respectively) $(\mathrm{p}<0.05)$. Also, a negative relation was determined between the kernel size with total flavonoids content $\left(R^{2}=0.917\right)$ and antioxidant capacity (according to FRAP and DPPH assays, $R^{2}=0.637$ ve $R^{2}=0.546$, respectively) ( $p$ $<0.05$ ). As a result, it was determined to have high values kernel of medium size in terms of oil content, kernel of large size with regard to the protein content and kernel of small size in terms of total phenolics content, total flavonoids content and antioxidant capacity.

Key words: Hazelnut, oil, protein, total phenolics, antioxidant

\section{Giriş}

Türkiye, dünya fındık üretimi ve ihracatında lider konumdadır. Ülkemiz 675 bin ton fındık üretimi ile dünya üretiminin yaklaşık \%67'sini sağlamaktadır (FAO, 2019). Bunun yanı sıra dünya fındık ihracatının ise yaklaşık \%90'ını ülkemiz gerçekleştirmektedir. Fındık sahip olduğu duyusal özellikler nedeni ile tüm dünyada sevilerek tüketilen bir meyve türüdür (Özdemir ve Akıncl, 2004; Amaral ve ark., 2006). Fındık doğal olarak tüketiminin yanı sıra kavrulmuş olarak da tüketilmektedir. Pasta, çikolata, şeker ve bisküvi sanayinde ham madde olarak kullanılan önemli ürünlerden biridir (Kaleoğlu ve ark., 2004; Özdemir ve Akıncl, 2004; İslam, 2018). Ayrıca çeșitli gıda ürünlerine lezzet katması amacı ile de kullanılmaktadır (Alasalvar ve ark., 2004; Oliveira ve ark., 2008).

Fındık, içeriğinde bulunan doymamış yağ asitleri (Balta ve ark., 2007; Kıralan ve ark., 2015), protein, karbonhidratlar, diyet lifi, vitaminler (Vitamin E) (Köksal ve ark., 2006), mineraller (Şimşek ve Aykut, 2007), fitoseroller (Yorulmaz ve ark., 2009), antioksidanlar ve fenolik bileşikler (Balık ve ark., 2017; Şahin, 2019) ile sert kabuklu meyve türleri arasında insan sağlığı ve beslenmesi açısından önemli bir yere sahiptir (Alasalvar ve ark., 2006). Bazı araştırıcılar fındığın içeriğindeki tekli doymamış yağ asitleri, çoklu doymamış yağ asitleri, tokoferoller, fitosteroller, polifenoller ve fitokimyasalların insan diyetinde önemli bir rolünün olduğunu bildirmişlerdir (Maguire ve ark., 2004; Alasalvar ve ark., 2006; Shahidi ve ark., 2007;
Mercanlıgil ve ark., 2007). Ayrıca fındık içeriğindeki antioksidanlar sayesinde kanser ve damar tıkanıklığı hastalıklarını önlemekte (Alasalvar ve ark., 2003), fitokimyasallar ve fenolik bileşikler sayesinde de kanserin ve oksidatif stresin zararlı etkilerine karşı koruma sağlamaktadır (Seabra ve ark., 2006; Alasalar ve Bolling, 2015).

Yapılan çalışmalarda findı̆̆ın kimyasal kompozisyonu üzerine ekolojik koşullar (Amaral ve ark., 2010), genotip (Parcerisa ve ark., 1993; Koyuncu ve ark., 1997a; Balta ve ark., 2006), bölge (Amaral ve ark., 2010), kültürel uygulamalar (Tonkaz ve ark., 2017a; Tonkaz ve ark., 2017b; Yaman, 2019), meyvenin olgunluk durumu (Koyuncu ve ark., 1997b; Seyhan ve ark., 2007; Cristofori ve ark., 2015), rakım ve yöneyin (Karadeniz ve Küp, 1997; Bostan, 2003; Beyhan ve ark., 2011) etkisinin olduğu bildirilmektedir.

$\mathrm{Bu}$ çalışma, Çarşamba (Samsun) yöresinde yoğun olarak yetiştiriciliği yapılan Çakıldak fındık çeşidinde iç meyve iriliğine göre biyokimyasal özelliklerin değișimini belirlemek amacı ile yürütülmüștür. Fındığın meyve iriliği ile insan sağlığını teşvik edici biyokimyasal özellikler arasındaki ilişkinin ortaya konulması neticesinde, iç findık olarak pazarlanmaya uygun olmayan findıkların işleme sanayinde farklı ürünlere katkı maddesi olarak kullanılarak, ürünün besleyicilik ve insan sağlığına yararlı özelliklerinin arttırılmasına olanak sağlayacağı düşünülmektedir.

\section{Materyal ve Yöntem}

\section{Materyal}

Çalışmada materyal olarak Çarşamba (Samsun) ilçesinde 12 yaşlı findık bahçesinde yetiştirilen Çakıldak çeşidine ait meyveler kullanılmıştır. Araştırma, 2018 yılında yürütülmüştür. Çalışmada materyal olarak kullanılan Çakıldak çeşidi adaptasyon yeteneği yüksek, meyve kalitesi iyi ve diğer fındık çeşitlerimize göre daha geç yapraklanmaktadır (Balık ve ark., 2016; Köksal, 2018). Çalışmanın yürütüldüğü bahçe ocak dikim sistemi kullanılarak, 4-6 dall, sıra arası 6 m ve sıra üzeri $4 \mathrm{~m}$ olacak şekilde tesis edilmiştir. Deneme süresince bahçede tüm kültürel uygulamalar eksiksiz olarak yerine getirilmiştir. Sulama, haziran, temmuz ve ağustos aylarında olmak üzere haftalık fasılalar ile damla sulama yöntemi kullanılarak yapılmıştır.

\section{Yöntem}

Çalışma tesadüf parselleri deneme desenine göre 3 tekerrürlü ve her tekerrürde 5 ocak olacak şekilde 
planlanmıștır. Hasat zamanında (25-30 Ağustos) her ocaktan ocă̆ı temsil edecek șekilde 100 adet çotanak derilerek, gözenekli file torbalar içerisine konulmuştur. Hasat edilen meyve örnekleri zuruflarından ayrıldıktan sonra oda sıcaklı̆̆ında $(24$ ${ }^{\circ} \mathrm{C}$ ) kurutulmuştur. Kurutulmuş olan meyve örnekleri kabukları kırıldıktan sonra TSE'nin iç fındık sınıflandırması (Anonim, 2019) modifiye edilerek, iç iriliğine göre küçük, orta ve büyük olmak üzere 3 gruba ayrılmıștır. İç meyve iriliği; iç meyve boyu, eni ve kalınlığının geometrik ortalaması alınarak hesaplanmıștır. Buna göre iç meyve iriliği 9.0-11.0 arasında olanlar 'küçük', 11.01-13.0 arasında olanlar 'orta' ve 13.01-15.0 arasında olanlar 'büyük' olarak tanımlanmıştır.

İç meyve iriliğine göre sinıflandırılmış olan meyvelerde biyokimyasal özellikler olarak yağ oranı, protein oranı, toplam fenolik, toplam flavonoid ve antioksidan kapasitesi (FRAP ve DPPH yöntemlerine göre) belirlenmiştir. Biyokimyasal analizlerde sağlam içe sahip olan meyveler kullanılmıştır. Toplam fenolik içeriği, toplam flavonoid içeriği ve antioksidan kapasitesi yağı alınmıș meyve örneklerinde tespit edilmiştir.

\section{Yağ oranı (\%)}

Yağ oranı soxhalet ekstraksiyon yöntemi kullanılarak belirlenmiş ve aşağıdaki formül kullanılarak, \% olarak ifade edilmiştir (AOCS, 1989).

$$
\text { Yağ oranı }(\%)=\frac{\text { M2-M1 }}{\text { M0 }} \times 100
$$

M0: Kurutulmuş fındık numunesinin ağırlı̆̆ı (g)

M1: Ekstraksiyon cihazı balonunun ağırlı̆̆ (g)

M2: Kurutma işleminden sonra ekstraksiyon cihazı balonunun ağırlı̆̆ (g)

\section{Protein Oranı (\%)}

Protein oranı kjeldahl yöntemi kullanılarak belirlenmiş ve aşağıdaki formül kullanılarak hesaplanmıștır. Hesaplanmış olan değerler \% olarak ifade edilmiştir (Venktachalam ve Sathe, 2006).

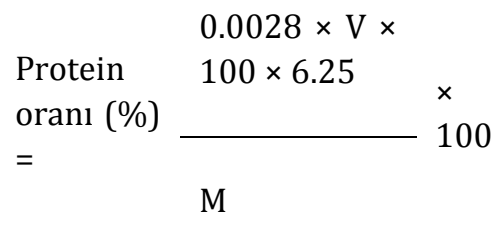

\footnotetext{
V: Kullanılan $\mathrm{HCl}$ çözeltisinin hacmi (ml)

M: Kullanılan fındık numunesinin ağırlığı (g)
}

\section{Toplam Fenolik İçeriği (mg $100 \mathrm{~g}^{-1}$ )}

Toplam fenolik madde tayini için hazırlanmış olan stok çözeltiden $1000 \mu \mathrm{L}$ alınarak üzerine $3600 \mu \mathrm{L}$ saf su, $100 \mu \mathrm{L}$ Folin-Ciocalteus ve $300 \mu \mathrm{L}$ sodyum karbonat $\left(\mathrm{Na}_{2} \mathrm{CO}_{3}\right)$ ilave edilmiştir. Hazırlanan çözelti 2 saat inkübasyona bırakılmıştır. İnkübasyon işleminden sonra numuneler spektrofotometrede $760 \mathrm{~nm}$ dalga boyunda okunmuştur. Elde edilen değerler gallik asit cinsinden hesaplanmış ve mg 100 $\mathrm{g}^{-1}$ olarak ifade edilmiştir (Beyhan ve ark., 2010).

\section{Toplam Flavonoid İçeriği (mg $\left.100 \mathrm{~g}^{-1}\right)$}

Hazırlanmış olan stok çözeltiden $1000 \mu \mathrm{L}$ alınarak, üzerine $3300 \mu \mathrm{L}$ methanol, $100 \mu \mathrm{L}$ aleminyum nitrat [Al $\left(\mathrm{NO}_{3}\right)_{3}$ ] ve $100 \mu \mathrm{L}$ amonyum asetat $\left(\mathrm{NH}_{4} \mathrm{CH}_{3} \mathrm{COO}\right)$ ilave edilmiştir. Hazırlanmış olan çözelti inkübasyon için $30 \mathrm{dk}$ bekletilmiştir. İnkübasyon işleminden sonra, spektrofotometrede $415 \mathrm{~nm}$ dalga boyunda okunmuş ve elde edilen değerler mg $100 \mathrm{~g}^{-1}$ olarak kuersetin cinsinden ifade edilmiştir (Zhishen ve ark., 1999).

\section{Antioksidan Kapasitesi FRAP Yöntemi ( $\left.\mu \mathrm{mol} 100 \mathrm{~g}^{-1}\right)$}

FRAP yöntemine göre antioksidan aktivitesini belirlemek için hazırlanan stok çözeltiden $20 \mu \mathrm{L}$ alınarak üzerine $1230 \mu \mathrm{L}$ fosfat tamponu ve $1250 \mu \mathrm{L}$ potasyum ferrik siyanit ilave edilmiștir. Hazırlanmış olan çözelti su banyosu içerisinde $50{ }^{\circ} \mathrm{C}^{\prime} \mathrm{de} 25 \mathrm{dk}$ süreyle inkübasyona bırakılmıştır. İnkübasyon işleminden sonra numunelerin üzerine $1250 \mu \mathrm{L}$ TCA ve $250 \mu \mathrm{L}$ demir klorür ilave edilmiştir. Hazırlanmış olan numune spektrofotometrede $700 \mathrm{~nm}$ dalga boyunda okunmuş ve elde edilen değerler torolox cinsinden hesaplanmış ve $\mu$ mol $100 \mathrm{~g}^{-1}$ torolox eşdeğeri olarak ifade edilmiştir (Benzie ve Strain, 1996).

\section{DPPH Yöntemi ( $\left.\mu \mathrm{mol} 100 \mathrm{~g}^{-1}\right)$}

Hazırlanmış olan stok çözeltiden $30 \mu \mathrm{L}$ alınarak, üzerine $2970 \mu \mathrm{L}$ etil alkol ve $0.26 \mathrm{mM} 1000 \mu \mathrm{L} \mathrm{DPPH}$ çözeltisi ilave edilmiştir. Hazırlanan çözelti $30 \mathrm{dk}$ süreyle inkübasyona bırakılmıştır. İnkübasyon işleminden sonra numuneler spektrofotometrede $517 \mathrm{~nm}$ dalga boyunda okunmuş ve elde edilen değerler $\mu \mathrm{mol} 100 \mathrm{~g}^{-1}$ torolox eşdeğeri olarak ifade edilmiştir (Blois, 1958).

\section{İstatistiksel Analizler}

Elde edilen verilerin değerlendirilmesinde SPSS 23.0 istatistik programı kullanılmıştır. Ortalamalar arasındaki farklılıklar \%5 önem seviyesinde Tukey çoklu karşlaştırma yöntemi kullanılarak belirlenmiştir. İncelenen özellikler arasındaki ilişki 
Pearson korelasyon katsayısı kullanılarak tespit edilmiștir.

\section{Bulgular ve Tartışma}

Çakıldak çeşidinde iç meyve iriliğine bağlı olarak yağ ve protein oranı değerleri Çizelge 1'de verilmiştir. İç meyve iriliğinin Çakıldak çeşidinde yağ oranı üzerine etkisi önemli bulunmuştur $(\mathrm{p}<0.05)$. Yağ oranı bakımından küçük ve büyük irilikteki meyveler istatistiksel olarak aynı grupta yer almıștır. İç meyve iriliğine göre yağ oranı \%56.74 (küçük)-58.02 (orta) arasında belirlenmiştir. Çakıldak fındık çeşidi ile yapılan farklı çalışmalarda yağ oranını Baş ve ark. (1986) Giresun'da \%55.07; İslam ve Özgüven (2001) Ordu'da \%59.24-62.77; Turan ve İslam (2016), Gürgentepe (Ordu) ilçesinde \%51.9; Balık ve ark. (2017) Giresun ekolojik koşullarında \%61.0; Çayan (2019) Gürgentepe yöresinde \%50.50-60.88 ve Yaman (2019) Çarşamba ilçesinde \%55.45-60.49 arasında belirlemiștir. Yağ oranı bakımından elde ettiğimiz bulgular genel olarak araştırıcıların bulguları ile uyumlu iken, İslam ve Özgüven (2001) ile Balık ve ark. (2017)'nın bulgularından ise düşük bulunmuştur. Farklı araştırıcılar findıkta yağ oranının ekolojik koşullara (Şahin ve ark., 1990; Amaral ve ark., 2010), teknik ve kültürel uygulamalara (Külahçılar, 2017; Yaman, 2019) bağlı olarak değișiklik gösterebileceğini bildirmișlerdir.

İç meyve iriliğine bağlı olarak protein oranı değerleri arasında görülen farklılık önemsiz bulunmuştur ( $p>0.05)$. İç meyve iriliğine göre protein oranı \%16.24 (küçük)-17.85 (büyük) arasında tespit edilmiştir. Çakıldak fındık çeşidi üzerine yapılan farklı çalışmalarda protein oranını Baş ve ark. (1986) \%17.58, İslam ve Özgüven (2001) Ordu'da \%15.4615.94, Turan ve İslam (2016), Gürgentepe ilçesinde \%14.42; Balık ve ark. (2017) Giresun ekolojik koşullarında \%16.02, Çayan (2019) Gürgentepe yöresinde \%15.10-20.70 ve Yaman (2019) Çarşamba ilçesinde \%14.74-16.00 arasında belirlemiștir. Protein oranı bakımından elde edilen bulgular araştırıcıların bildirmiş olduğu referans değerleri arasında yer almaktadır.

Çizelge 1. Çakıldak çeşidinde iç meyve irilik sinıflarına göre yağ ve protein oranı

\begin{tabular}{ccc}
\hline Meyve İrilik Sınıfları & Yağ Oranı (\%) & Protein Oranı (\%) \\
\hline Küçük & $56.74 \mathrm{~b}^{*}$ & $16.24 \mathrm{a}$ \\
Orta & $58.02 \mathrm{a}$ & $16.91 \mathrm{a}$ \\
Büyük & $57.06 \mathrm{~b}$ & $17.85 \mathrm{a}$ \\
\hline
\end{tabular}

*Aynı sütunda aynı harf ile gösterilen ortalamalar arasındaki fark önemsizdir $(\mathrm{p}<0.05)$.
Çakıldak çeşidinde iç meyve iriliğine bağlı olarak toplam fenolik ve toplam flavonoid içeriğine ait veriler Çizelge 2'de sunulmuştur. Çakıldak çeşidinde iç meyve iriliğine bağlı olarak toplam fenolik içeriğine ait değerler arasında istatistiksel olarak önemli bir farklılık tespit edilmiştir $(\mathrm{p}<0.05)$. İç meyve iriliğine göre toplam fenolik içeriği 662.3 (orta)-763.5 (küçük) mg 100 g-1 arasında değişiklik göstermiştir. Toplam fenolik içeriğini Altun ve ark. (2013) Giresun ekolojik koşullarında yetiştirilen Çakıldak çeşidinde 612.0 mg $100 \mathrm{~g}^{-1}$, Pelvan ve ark. (2012) Giresun'da yetiştirilen Çakıldak çeşidinde 246.0 mg $100 \mathrm{~g}^{-1}$, Balık ve ark. (2017) Giresun yöresinde yetiştirilen Çakıldak çeşidinde $741.0 \mathrm{mg}$ $100 \mathrm{~g}^{-1}$ olarak belirlemişlerdir. Toplam fenolik içeriği bakımından elde edilen bulgular Altun ve ark. (2013) ve Balık ve ark. (2017)'nın bulguları ile uyumlu iken, Pelvan ve ark. (2012)'nın bulgularından ise yüksek bulunmuştur. Görülen farklılı̆̆ın ekolojik koşullardan, bölgeden (Amaral ve ark., 2010), teknik ve kültürel uygulamalardan (Tonkaz ve ark., 2017b) ve meyvenin olgunluk durumundan (Seyhan ve ark., 2007; Cristofori ve ark., 2015) kaynaklı olabileceği düşünülmektedir.

Çakıldak çeşidinde toplam flavonoid içeriği üzerine iç meyve iriliğinin etkisi istatistiksel olarak önemli bulunmuştur $(\mathrm{p}<0.05)$. İç meyve iriliğine göre toplam flavonoid içeriği 5.42 (büyük)-11.56 (küçük) mg $100 \mathrm{~g}^{-1}$ arasında tespit edilmiştir. Balık ve ark. (2017) Giresun ekolojik koşullarında yetiştirilen Çakıldak çeşidinde toplam flavonoid içeriğini 12.7 mg $100 \mathrm{~g}^{-1}$ olarak tespit etmişlerdir. Elde edilen toplam flavonoid değerleri Balık ve ark. (2017)'nın bulgularından düşük bulunmuştur. Görülen farklılığın ekolojik faktörlerden ve meyvenin olgunluk durumundan kaynaklı olabileceği düşünülmektedir.

Çizelge 2. Çakıldak çeşidinde iç meyve irilik sinıflarına toplam fenolik ve toplam flavonoid içeriği

\begin{tabular}{ccc}
\hline Meyve İrilik Sinıfları & $\begin{array}{c}\text { Toplam Fenolik } \\
\left(\mathrm{mg} 100 \mathrm{~g}^{-1}\right)\end{array}$ & $\begin{array}{c}\text { Toplam Flavonoid } \\
\left(\mathrm{mg} 100 \mathrm{~g}^{-1}\right)\end{array}$ \\
\hline Küçük & $763.5 \mathrm{a}$ & $11.56 \mathrm{a}$ \\
Orta & $662.3 \mathrm{c}$ & $7.63 \mathrm{~b}$ \\
Büyük & $708.9 \mathrm{~b}$ & $5.42 \mathrm{c}$ \\
\hline
\end{tabular}

*Aynı sütunda aynı harf ile gösterilen ortalamalar arasındaki fark önemsizdir $(\mathrm{p}<0.05)$.

Çakıldak çeşidinde iç meyve iriliğine bağlı olarak antioksidan kapasitesi değerleri Çizelge 3'te verilmiştir. FRAP ve DPPH testlerine göre, Çakıldak çeşidinde iç meyve iriliğine göre antioksidan 
kapasitesi değerleri arasında istatistiksel olarak önemli bir farklılık bulunmuştur $(\mathrm{p}<0.05)$. Bunun yanı sıra DPPH testine göre antioksidan kapasitesi bakımından orta ve büyük irilikteki meyveler istatistiksel olarak aynı grupta yer almıştır. İç meyve iriliğine bağlı olarak antioksidan kapasitesi FRAP testine göre 3348.0 (orta)-5883.3 (küçük) $\mu$ mol 100 $\mathrm{g}^{-1}$, DPPH testine göre ise 3160.0 (orta)-4418.2 (küçük) $\quad \mu$ mol $100 \quad \mathrm{~g}^{-1}$ arasında değişiklik göstermiştir.

Çizelge 3. Çakıldak çeşidinde iç meyve irilik sınıflarına göre antioksidan kapasitesi

\begin{tabular}{ccc}
\hline Meyve İrilik Sinıfları & FRAP $\left(\mu \mathrm{mol} 100 \mathrm{~g}^{-1}\right)$ & DPPH $\left(\mu \mathrm{mol} 100 \mathrm{~g}^{-1}\right)$ \\
\hline Küçük & $5883.3 \mathrm{a}$ & $4418.2 \mathrm{a}$ \\
Orta & $3348.0 \mathrm{c}$ & $3160.0 \mathrm{~b}$ \\
Büyük & $3987.2 \mathrm{~b}$ & $3506.6 \mathrm{~b}$ \\
\hline
\end{tabular}

*Aynı sütunda aynı harf ile gösterilen ortalamalar arasındaki fark önemsizdir $(\mathrm{p}<0.05)$.

Toplam antioksidan kapasitesini Altun ve ark. (2013) Giresun ekolojik koşullarında yetiștirilen Çakıldak çeșidinde ABTS testine göre $2310.0 \mu \mathrm{mol}$ $100 \mathrm{~g}^{-1}$ ve CUPRAC testine göre ise $2720.0 \mu \mathrm{mol} 100$ $\mathrm{g}^{-1}$ olarak, Pelvan ve ark. (2012) Giresun'da yetiştirilen Çakıldak çeşidinde ORAC testine göre $7323.0 \mu \mathrm{mol} 100 \mathrm{~g}^{-1}$ olarak, Balık ve ark. (2017) Giresun yöresinde yetiştirilen Çakıldak çeşidinde FRAP testine göre $1950.3 \mu \mathrm{mol} 100 \mathrm{~g}^{-1}$ ve DPPH testine göre ise $2536.5 \mu \mathrm{mol} 100 \mathrm{~g}^{-1}$ olarak belirlemişlerdir. Farklı araştırıcıların yapmış olduğu çalışmalarda da görüldüğü üzere antioksidan kapasitesi değerleri kullanılan yönteme göre farklılık göstermektedir. Bunun yanı sıra elde edilen değerler antioksidan kapasitesini belirlemek için benzer yöntemleri kullanan Balık ve ark. (2017)'nın değerlerinden yüksek bulunmuştur. Görülen farklılıkların ekolojik faktörlerden, bölgeden (Amaral ve ark., 2010), kültürel uygulamalardan (Tonkaz ve ark., 2017b) ve meyvenin olgunluk durumundan
(Seyhan ve ark., 2007; Cristofori ve ark., 2015) kaynaklı olabileceği düşünülmektedir.

İç meyve iriliği ile toplam flavonoid içeriği ( $\mathrm{r}=$ $0.957^{* * *}$ ) ve antioksidan kapasitesi (FRAP ve DPPH testlerine göre) $\left(r=-0.799^{* *}\right.$ ve $\left.r=-0.739 *\right)$ arasında negatif bir korelasyon belirlenmiștir $(\mathrm{p}<0.05)$. Bunun yanı sıra iç meyve iriliği ile yağ oranı, protein oranı ve toplam fenolik içeriği arasındaki korelasyon önemsiz bulunmuştur ( $\mathrm{p}>0.05)$. Yağ oranı ile toplam fenolik içeriği $\left(\mathrm{r}=-0.813^{* *}\right)$ ve antioksidan kapasitesi arasinda (FRAP ve DPPH testlerine göre) $(r=-0.729 *$ ve $r=-0.712^{*}$ ) negatif bir korelasyon tespit edilmiştir $(\mathrm{p}<0.05)$. Ayrıca toplam fenolik içeriği ile antioksidan kapasitesi arasında (FRAP ve DPPH testlerine göre) ( $\mathrm{r}=959^{* * *}$ ve $\left.\mathrm{r}=0.971^{* * *}\right)$, toplam flavonoid ile antioksidan kapasitesi arasında (FRAP ve DPPH testlerine göre) ( $r=771^{*}$ ve $\left.r=0.745^{*}\right)$ ve FRAP testi ile DPPH testi arasında ( $\left.\mathrm{r}=959^{* * *}\right)$ pozitif bir korelasyon belirlenmiştir $(\mathrm{p}<0.05)$ (Çizelge 4). Farklı meyve türleri ile yapılan çalışmalarda toplam fenolik içeriği ile antioksidan kapasitesi arasında (Isfahlan ve ark., 2010; Contini ve ark., 2012; Gharibzahedi ve ark., 2013) ve toplam flavonoid içeriği ile antioksidan kapasitesi arasında (Pantelidis ve ark., 2007; Okatan ve ark., 2018) pozitif bir korelasyonun olduğu bildirilmiştir.

İç meyve iriliği ile toplam flavonoid içeriği $\left(\mathrm{R}^{2}=0.917\right)$ ve antioksidan kapasitesi (FRAP ve DPPH testlerine göre) $\left(\mathrm{R}^{2}=0.637\right.$ ve $\left.\mathrm{R}^{2}=0.546\right)$ arasında negatif bir ilişki belirlenmiştir $(\mathrm{p}<0.05)$. Bunun yanı sıra yağ oranı ile toplam fenolik içeriği $\left(\mathrm{R}^{2}=0.661\right)$ ve antioksidan kapasitesi (FRAP ve DPPH testlerine göre, sırasiyla $R^{2}=0.531$ ve $R^{2}=0.507$ ) arasinda negatif bir ilişki tespit edilmiştir $(\mathrm{p}<0.05)$ (Şekil 1). Buna karşılık, toplam fenolik içeriği ile antioksidan kapasitesi arasında (FRAP ve DPPH testlerine göre, sirasiyla $R^{2}=0.920$ ve $R^{2}=0.942$ ), toplam flavonoid içeriği ile antioksidan kapasitesi arasında (FRAP ve DPPH testlerine göre) $\left(R^{2}=0.595\right.$ ve $\left.R^{2}=0.555\right)$ ve FRAP ile DPPH $\left(\mathrm{R}^{2}=0.921\right)$ arasında pozitif bir ilişki belirlenmiştir $(\mathrm{p}<0.05)$ (Şekil 2).

Çizelge 4. Çakıldak çeşidinde incelenen özelliklere ait korelasyon katsayısı değerleri

\begin{tabular}{lllllll}
\hline & İç meyve iriliği & Yağ oranı & Protein oranı & Toplam fenolik & Toplam flavonoid & FRAP \\
\hline İç meyve iriliği & 1 & & & & & \\
Yağ oranı & $0.312^{\text {öd }}$ & 1 & & & & \\
Protein oranı & $0.578^{\text {öd }}$ & $0.205^{\text {öd }}$ & 1 & & \\
Toplam fenolik & $-0.620^{\text {öd }}$ & $-0.813^{* *}$ & $-0.249^{\text {öd }}$ & 1 & & \\
Toplam flavonoid & $-0.957^{* * *}$ & $-0.394^{\text {öd }}$ & $-0.528^{\text {od }}$ & $0.625^{\text {ö }}$ & 1 & \\
FRAP & $-0.799^{* *}$ & $-0.729^{*}$ & $-0.372^{\text {öd }}$ & $0.959^{* * *}$ & $0.771^{*}$ & \\
DPPH & $-0.739^{*}$ & $-0.712^{*}$ & $-0.362^{\text {öd }}$ & $0.971^{* * *}$ & $0.745^{*}$ & $0.959^{* * *}$ \\
\hline
\end{tabular}

p değeri: $\mathrm{p}<0.05^{*} ; \mathrm{p}<0.005^{* *} ; \mathrm{p}<0.001^{* * *} ; \mathrm{p}>0.05^{\circ \mathrm{od}}$ 

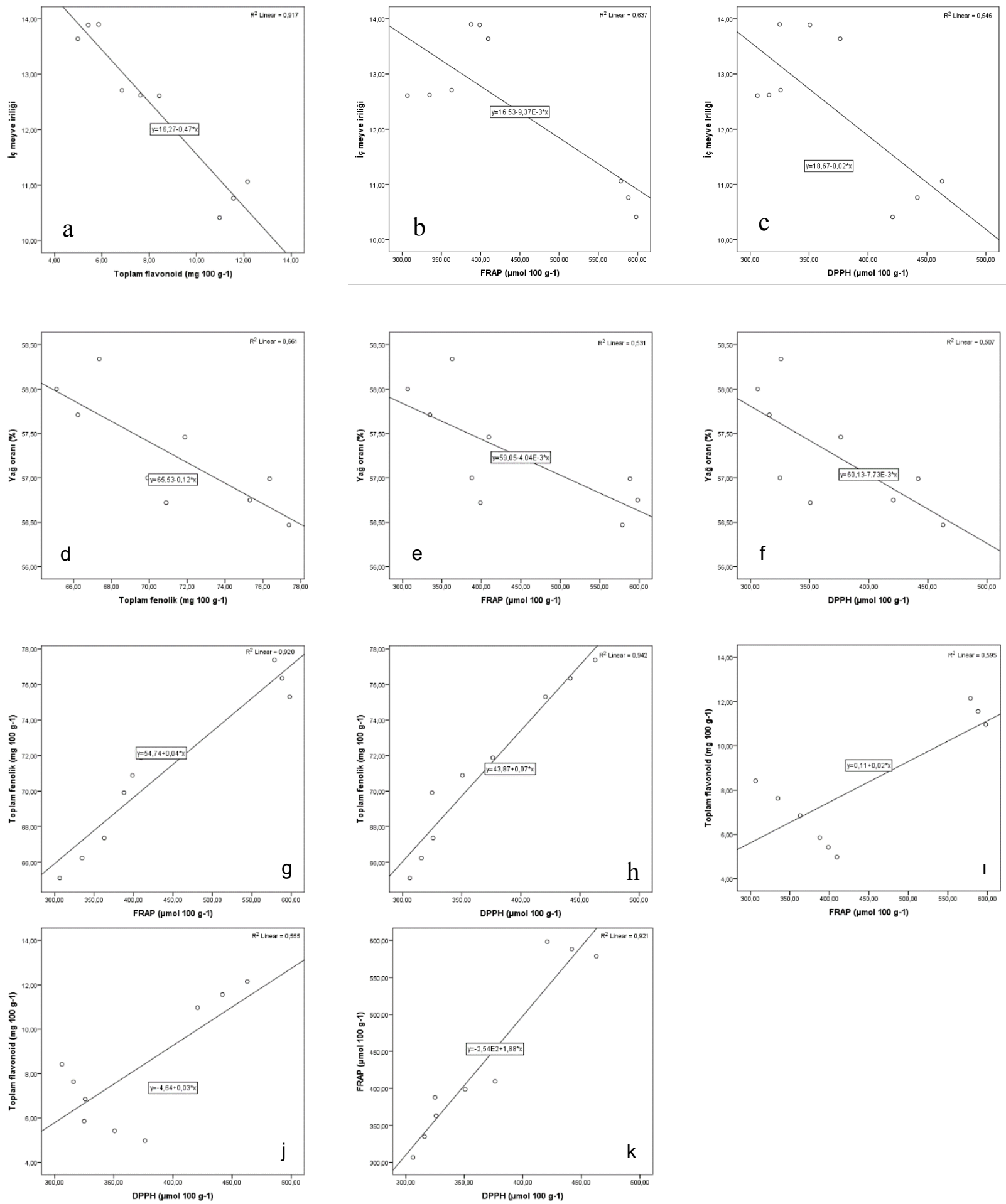

Şekil 2. Çakıldak çeşidinde iç meyve iriliği ile toplam flavonoid içeriği (a), FRAP (b) ve DPPH (c) yağ oranı ile toplam fenolik içeriği (d), FRAP (e) ve DPPH (f); toplam fenolik içeriği ile FRAP (g) ve DPPH (h); toplam flavonoid içeriği ile FRAP (l) ve DPPH (j); FRAP ve DPPH (k) arasındaki ilişki 
Contini ve ark. (2012) findikta toplam fenolik ve antioksidan kapasitesi $\left(\mathrm{R}^{2}=0.96\right)$ arasında pozitif bir ilişkinin olduğunu bildirilmişlerdir. Farklı meyve türleri ile yapılan çalışmalarda Isfahlan ve ark. (2010) bademde toplam fenolik içeriği ve antioksidan kapasitesi (FRAP testine göre $\mathrm{R}^{2}=0.98$ ) arasında, Tosun ve ark. (2011) cevizde toplam fenolik içeriği ve antioksidan kapasitesi arasında (FRAP testine göre $\mathrm{R}^{2}=0.96$, TEAC testine göre $\mathrm{R}^{2}=0.78$ ) pozitif bir ilişkinin olduğunu tespit etmişlerdir.

\section{Sonuç}

Çakıldak çeşidinde protein oranı hariç incelenen diğer biyokimyasal özelliklerin iç meyve iriliğine bağlı olarak önemli bir değişim gösterdiği belirlenmiştir. Genel olarak, küçük iç iriliğine sahip meyvelerin biyokimyasal özellikler bakımından yüksek değerlere sahip olduğu tespit edilmiştir. İç meyve iriliği ile toplam flavonoid içeriği ve antioksidan kapasitesi arasında negatif bir ilişkinin olduğu belirlenmiştir.

Bunun yanı sıra antioksidan kapasitesi ile toplam fenolik ve toplam flavonoid içeriği arasında güçlü bir korelasyon olduğu tespit edilmiştir. Ayrıca, iç fındık olarak pazarlanmaya uygun olmayan findıkların işleme sanayinde farklı ürünlere katkı maddesi olarak kullanılarak, ürünün besleyicilik ve insan sağlığına yararlı özelliklerinin arttırılmasına olanak sağlayacağı düşünülmektedir.

\section{Kaynaklar}

Alasalvar, C., Amaral, J.S., Shahidi, F., 2006. Functional lipid characteristics of Turkish Tombul hazelnut (Corylus avellana L.). Journal of agricultural and food chemistry, 54(26): 10177-10183.

Alasalvar, C., Bolling, B.W., 2015. Review of nut phytochemicals, fat-soluble bioactives, antioxidant components and health effects. British Journal of Nutrition, 113(S2): 68-78.

Alasalvar, C., Odabasi, A. Z., Demir, N., Balaban, M. Ö., Shahidi, F., Cadwallader, K.R., 2004. Volatiles and flavor of five Turkish hazelnut varieties as evaluated by descriptive sensory analysis, electronic nose, and dynamic headspace analysis/gas chromatography-mass spectrometry. Journal of Food Science, 69(3): 99106.
Alasalvar, C., Shahidi, F., Cadwallader, K.R., (2003). Comparison of natural and roasted Turkish Tombul hazelnut (Corylus avellana L.) volatiles and flavor by DHA/GC/MS and descriptive sensory analysis. Journal of Agricultural and Food Chemistry, 51(17): 5067-5072.

Altun, M., Celik, S.E., Güçlü, K., Özyürek, M., Erçağ, E., Apak, R., 2013. Total antioxidant capacity and phenolic contents of Turkish hazelnut (Corylus avellana L.) kernels and oils. Journal of Food Biochemistry, 37(1): 53-61.

Amaral, J. S., Valentao, P., Andrade, P.B., Martins, R.C., Seabra, R.M., 2010. Phenolic composition of hazelnut leaves: Influence of cultivar, geographical origin and ripening stage. Scientia Horticulturae, 126(2): 306-313.

Amaral, J.S., Casal, S., Alves, M.R., Seabra, R.M., Oliveira, B.P., 2006. Tocopherol and tocotrienol content of hazelnut cultivars grown in Portugal. Journal of Agricultural and Food Chemistry, 54(4): 13291336.

Anonim, 2019. Türk Standartları Enstitüsü, TSE 3075 İç Findık Standardı. https://www.tse.org.tr/. (Erişim tarihi: 12.05.2019).

AOCS, 0.0., 1989. Official and Recommended Methods of the American Oil Chemists' Society. AOCS Press, Champaign.

Balık, H.I., Karakaya, O., Öztürk, B., Gün, S., Öztürk, A., 2017. Bioactive compounds of Turkish hazelnut cultivars, IX. International Congress on Hazelnut (15-19 August 2017, Samsun/Turkey),189.

Balık, H.İ, Kayalak-Balık, S., Beyhan, N., Erdoğan, V., 2016. Fındık Çeşitleri. Trabzon Ticaret Borsası Yayınları, Trabzon, 96s.

Balta, M. F., Yarılgaç, T., Aşkın, M. A., Kuçuk, M., Balta, F., Özrenk, K., 2006. Determination of fatty acid compositions, oil contents and some quality traits of hazelnut genetic resources grown in eastern Anatolia of Turkey. Journal of Food Composition and Analysis, 19(6-7): 681-686.

Baş, F., Ömeroğlu, S., Türdü, S., Aktaş, S., 1986. Önemli Türk fındık çeşitlerinin bileşim özelliklerinin saptanması. GIDA, 11(4): 194-203.

Benzie, I.F., Strain, J.J., 1996. The ferric reducing ability of plasma (FRAP) as a measure of "antioxidant power": the FRAP assay. Analytical Biochemistry, 239(1): 70-76. 
Beyhan, O., Elmastas, M., Genc, N., Aksit, H., 2011. Effect of altitude on fatty acid composition in Turkish hazelnut (Coryllus avellana L.) varieties. African Journal of Biotechnology, 10(71): 16064-16068.

Beyhan, Ö., Elmastas, M., Gedikli, F., 2010. Total phenolic compounds and antioxidant capacity of leaf, dry fruit and fresh fruit of feijoa (Acca sellowiana, Myrtaceae). Journal of Medicinal Plants Research, 4(11): 1065-1072.

Blois, M.S., 1958. Antioxidant determinations by the use of a stable free radical. Nature, 181(4617): 1199. 1200.

Bostan, S. Z., 2003. Important chemical and physical traits and variation in these traits in 'Tombul' hazelnut cultivar at different elevations. Grasas y Aceites, 54(3): 234-239.

Contini, M., Baccelloni, S., Frangipane, M. T., Merendino, N., Massantini, R., 2012. Increasing espresso coffee brew antioxidant capacity using phenolic extract recovered from hazelnut skin waste. Journal of Functional Foods, 4(1): 137-146.

Cristofori, V., Bertazza, G., Bignami, C., 2015. Changes in kernel chemical composition during nut development of three Italian hazelnut cultivars. Fruits, 70(5): 311-322.

Çayan, M., 2019. Ordu İli Gürgentepe İlçesinde Yetiştirilen Çakıldak Fındık Çeşidinde Klon Seleksiyonu. Ordu Üniversitesi, Fen Bilimleri Enstitüsü, Yüksek Lisans Tezi. Ordu, $99 \mathrm{~s}$.

FAO, 2019. Food and Agriculture Organization of the United State. http://www.fao.org/home/en/. (Erişim tarihi: 17.09.2019).

Gharibzahedi, S.M.T., Mousavi, S.M., Hamedi, M., Rezaei, K., Khodaiyan, F., 2013. Evaluation of physicochemical properties and antioxidant activities of Persian walnut oil obtained by several extraction methods. Industrial crops and products, 45(2013): 133-140.

Isfahlan, A. J., Mahmoodzadeh, A., Hasanzadeh, A., Heidari, R., Jamei, R., 2010. Antioxidant and antiradical activities of phenolic extracts from Iranian almond (Prunus amygdalus L.) hulls and shells. Turkish Journal of Biology, 34(2): 165-173.

İslam, A. 2018. Hazelnut culture in Turkey. Akademik Ziraat Dergisi 7(2), 259-66. doi:10.29278/azd.476665.
İslam, A., Özgüven, A.I., 2001. Clonal selection in the Turkish hazelnut cultivars grown in Ordu province. Acta Horticulture, 556: 203-208.

Kaleoğlu, M., Bayindirli, L., Bayindirli, A., 2004. Lye peeling of 'Tombul'hazelnuts and effect of peeling on quality. Food and Bioproducts Processing, 82(3): 201-206.

Karadeniz, T., Küp, M., 1997. The effects on quality hazelnut of direction. Acta Horticulture, 445: 285294.

Kıralan, S., Yorulmaz, A., Şimşek, A., Tekin, A., 2015. Classification of Turkish hazelnut oils based on their triacylglycerol structures by chemometric analysis. European Food Research and Technology, 240(4): 679-688.

Koyuncu, M.A., Balta, F., Koyuncu, F., Balta, M.F., 1997a. Main composition of the fruits of the hazelnuts Tombul and Palaz cultivars preselected in Carsamba and Terme (Samsun) districts. Acta Horticulturae 445: 119-122

Koyuncu, M.A., Koyuncu, F., Bostan, S.Z., İslam, A., 1997b. Change of fat content and fatty acid composition during the fruit development period in the hazelnuts Tombul and Palaz cultivars grown in Ordu. Acta Horticulturae 45: 229-236.

Köksal, A. İ., Artık, N., Şimşek, A., Güneş, N., 2006. Nutrient composition of hazelnut (Corylus avellana L.) varieties cultivated in Turkey. Food Chemistry, 99(3): 509-515.

Köksal, İ., 2018. Türk Fındık Çeşitleri. Fındık tanıtım Grubu Yayınları, Ankara, 136s.

Maguire, L. S., O'sullivan, S. M., Galvin, K., O'connor, T. P., O'brien, N.M., 2004. Fatty acid profile, tocopherol, squalene and phytosterol content of walnuts, almonds, peanuts, hazelnuts and the macadamia nut. International Journal of Food Sciences and Nutrition, 55(3): 171-178.

Mercanlıgil, S. M., Arslan, P., Alasalvar, C., Okut, E., Akgül, E., Pınar, A., Geyik, P.Ö., Tokgözoğlu, L., Shahidi, F., 2007. Effects of hazelnut-enriched diet on plasma cholesterol and lipoprotein profiles in hypercholesterolemic adult men. European Journal of Clinical Nutrition, 61(2): 212.

Okatan, V., Bulduk, I., Sekara, A., Colak, A. M., Kaki, B., Gundogdu, M., 2018. Bioactive components and market quality of apple (Malus domestica Borkh.) fruits could be effectively controlled by trees pretreatment with boric acid, melatonin and gibberellic acid. Fresenius Environmental Bulletin, 27(10): 6933-6944. 
Oliveira, I., Sousa, A., Morais, J.S., Ferreira, I.C., Bento, A., Estevinho, L., Pereira, J.A., 2008. Chemical composition, and antioxidant and antimicrobial activities of three hazelnut (Corylus avellana L.) cultivars. Food and Chemical Toxicology, 46(5): 1801-1807.

Ozdemir, F., Akinci, I. 2004. Physical and nutritional properties of four major commercial Turkish hazelnut varieties. Journal of Food Engineering, 63(3): 341-347.

Pantelidis, G.E., Vasilakakis, M., Manganaris, G.A., Diamantidis, G.R., 2007. Antioxidant capacity, phenol, anthocyanin and ascorbic acid contents in raspberries, blackberries, red currants, gooseberries and Cornelian cherries. Food Chemistry, 102(3): 777-783.

Parcerisa, J., Boatella, J., Codony, R., Farrà, A., Garcia, J., Lopez, A., Rafecas, M., Romero, A. (1993). Influence of variety and geographical origin on the lipid fraction of hazelnuts (Corylus avellana L.) from Spain: I. Fatty acid composition. Food Chemistry, 48(4): 411-414.

Pelvan, E., Alasalvar, C., Uzman, S., 2012. Effects of roasting on the antioxidant status and phenolic profiles of commercial Turkish hazelnut varieties (Corylus avellana L.). Journal of Agricultural and Food Chemistry, 60(5): 1218-1223.

Seabra, R.M., Andrade, P.B., Valentao, P., Fernandes, E., Carvalho, F., Bastos, M.L., 2006. Biomaterials From Aquatic And Terrestrial Organisms, Bocca Raton, CRC Press, 622 s.

Seyhan, F., Ozay, G., Saklar, S., Ertaş, E., Satır, G., Alasalvar, C., 2007. Chemical changes of three native Turkish hazelnut varieties (Corylus avellana L.) during fruit development. Food Chemistry, 105(2): 590-596.

Shahidi, F., Alasalvar, C., Liyana-Pathirana, C.M., 2007. Antioxidant phytochemicals in hazelnut kernel (Corylus avellana L.) and hazelnut byproducts. Journal of Agricultural and Food Chemistry, 55(4): 1212-1220.

Simsek, A., Aykut, O., 2007. Evaluation of the microelement profile of Turkish hazelnut (Corylus avellana L.) varieties for human nutrition and health. International Journal of Food Sciences and Nutrition, 58(8): 677-688.
Şahin, İ., Erkut, A., Öztek, L., Üstün, Ş., Oysun, G., 1990. Orta ve Doğu Karadeniz Bölgesinde yetiştirilen fındık çeşitlerinin teknolojik özellikleri üzerinde araștırmalar. Ondokuz Mayıs Üniversitesi Yayınları, 63: 54 .

Şahin, S., Kılıç, Ö., Şengül, S., Perçin, S., 2019. Farklı İllerden Temin Edilen Fındık Zarının Bileşimi ve Antioksidan Etkinliğinin Araştırılması. Ordu Üniversitesi Bilim ve Teknoloji Dergisi, 9(1): 27-35.

Thompson, M. M., SA, M., 1996. Hazelnuts. Fruits Breeding (Edited by Jules Janick and James N. Moore). Volume III, Chapter 3, p 184.

Tonkaz, T., Bostan, S. Z., Korkmaz, K., 2017a. Effects of supplematry irrigation on hazelnut yield and pomological traits, IX. International Congress on Hazelnut (15-19 August 2017, Samsun/Turkey),134.

Tonkaz, T., Sahin, S., Bostan, S. Z., Korkmaz, K., 2017b. Antioxidant activity and phenolic content of hazelnut fruit grown under different irrigation conditions, IX. International Congress on Hazelnut (15-19 August 2017, Samsun/Turkey),74.

Tosun, M., Celik, F., Ercisli, S.O., Yilmaz, S., 2011. Bioactive contents of commercial cultivars and local genotypes of walnut (Juglans regia L.). International Proceedings of Chemical, Biological and Environmental Engineering,15 (2011): 110114

Turan, A., İslam, A., 2016. Çakıldak fındık çeşidinde kurutma ortamları ve muhafaza süresine bağlı olarak meydana gelen değişimler. Ordu Üniversitesi Bilim ve Teknoloji Dergisi, 6(2): 272285.

Venkatachalam, M., Sathe, S.K., 2006. Chemical composition of selected edible nut seeds. Journal of Agricultural and Food Chemistry, 54(13): 47054714.

Yaman, İ., 2019. Çarşamba (Samsun) İlçesinde Bakımlı ve Bakımsız Fındık Bahçelerinde Yetiştirilen Çakıldak Çeşidinin Verim ve Meyve Özeliklerinin Belirlenmesi. Ordu Üniversitesi, Fen Bilimleri Enstitüsü, Yüksek Lisans Tezi. Ordu, 61 s. 
Yorulmaz, A., Velioglu, Y.S., Tekin, A., Simsek, A., Drover, J.C., Ates, J., 2009. Phytosterols in 17 Turkish hazelnut (Corylus avellana L.) cultivars. European Journal of Lipid Science and Technology, 111(4): 402-408.
Zhishen, J., Mengcheng, T., Jianming, W., 1999. Research on antioxidant activity of flavonoids from natural materials. Food Chemistry, 64(1999): 555-559. 